ח

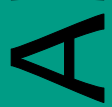

n

Ш

Z

O

$\underline{-}$

$F$

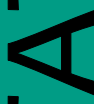

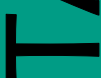

ه

Ш

n

n

$\overline{0}$
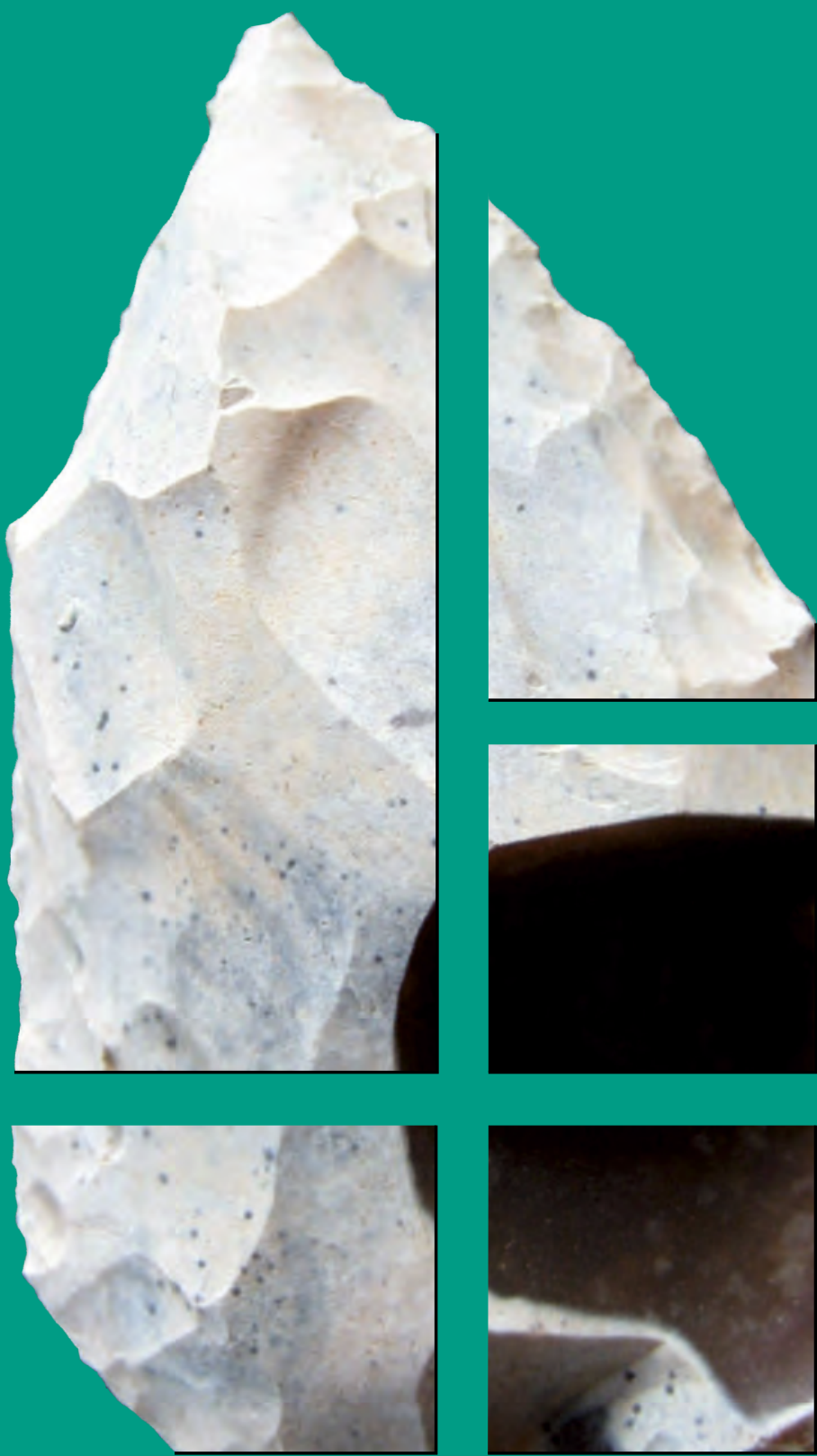

Ser. 3. No.9.| 2021 


\section{Dissertationes Archaeologicae ex Instituto Archaeologico}

Universitatis de Rolando Eötvös nominatae

Ser. 3. No. 9.

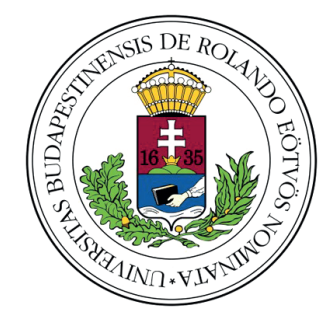

Budapest 2021 


\section{Dissertationes Archaeologicae ex Instituto Archaeologico Universitatis de Rolando Eötvös nominatae}

Ser. 3. No. 9.

Editor-in-chief

Dávid BARTus

Editorial board

László Bartosiewicz (Stockholm University, Stockholm)

Ondřej Chvojкa (University of South Bohemia, České Budějovice)

Zoltán Czajlik (Eötvös Loránd University, Budapest)

Mario Gavranović (Austrian Arhaeological Institute AAS, Vienna)

Hajnalka Herold (University of Exeter, Exeter)

Klára Kuzmová (University of Trnava, Trnava)

Tina Milavec (University of Ljubljana, Ljubljana)

Gábor V. Szabó (Eötvös Loránd University, Budapest)

Tivadar VIDA (Eötvös Loránd University, Budapest)

Technical editor

Gábor VÁcZI

Proofreading

Eszter TímÁr

Strobe DrIVER

Borbála MoHÁcsI

Fruzsina NÉMETH

Eli J. S. WeAVERDYCKE

Aviable online at http://ojs.elte.hu/dissarch

Contact: dissarch@btk.elte.hu

ISSN 2064-4574 (online)

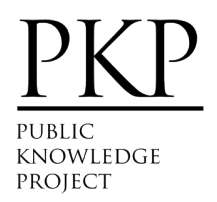

(c ELTE Eötvös Loránd University, Institute of Archaeological Sciences

Layout and cover design: Gábor Váczi

Budapest 2021 


\section{CONTEnTs}

\section{ARTiCles}

Attila PÉNTEK - Norbert FARAgó

Palaeolithic and Mesolithic assemblages from Tunisia

Attila PÉNTEK - Norbert FARAGó

Some remarks on a German chipped stone lithic assemblage of uncertain origin in the collection of the Institue of Archaeological Sciences, Eötvös Loránd University

László Gucsi

Technological observations on a Late Copper Age ceramic assemblage

from Hódmezővásárhely-Kopáncs-Olasz-tanya, Hungary

János Gábor TARBAY

101

A Koszider Period Sword from Tornyospálca-Sírkútgaz (Szabolcs-Szatmár-Bereg County, Hungary)

Ábel GARCZIK

Dolia in the Middle La Tène Period of the Carpathian Basin in the light of new finds from Perkáta-Nyúli-dűlő

Lajos JuHÁsz

An exceptional Sarmatian cast medallion with star and crescent

Gabriella G. DeLBó

New data on the Pannonian glazed casserole handles

Csilla SÁró

The fibula production of Brigetio: Model, semi-finished products, and failed castings

Anita BENES

New data on the capacity of the Roman aqueduct of Brigetio

Melinda SzABó

Status or Role? Differences between the Social Status and Role in Brigetio

Krisztina HoppáL

Roman engraved gems from Southeast Asia 


\section{FiELD REPORTS}

Bence SIMON - Ferenc BARNA

Another barrel-lined well a road section and late Roman graves from Brigetio

Rita RAKONCZAY

Trial excavations in mediaeval churches of Kishartyán, Kisterenye, Mátranovák and Szuha in Nógrád County 2021

\section{Thesis Review Articles}

Tamás KEszi

The change of the pottery style of the Mako and Nagyrév cultures in the Early Bronze Age:

The settlement in Iváncsa-Lapos

Linda Dobosi

Building techniques and building materials in Brigetio:

With the virtual reconstruction of House I/a of the civil town of Brigetio

Csilla SÁRó

Tradition and Romanization by the attire of the Eraviscus tribe 


\title{
Dolia in the Middle La Tène Period of the Carpathian Basin in the light of new finds from Perkáta-Nyúli-dűlő
}

\author{
Ábel GARCZIK \\ Institute of Archaeological Sciences \\ Eötvös Loránd University \\ garczikabel@gmail.com
}

Received 8 October 2021 | Accepted 12 November 2021 | Published 2 March 2022

\begin{abstract}
The excavations carried out by the Hungarian National Museum in Perkáta-Nyúli-dúlő have revealed the remains of a Late Iron Age settlement. Two large ceramic storage containers found in a house of this settlement, dating from the La Tène $\mathrm{C} 1-\mathrm{C} 2$ period, are in the focus of the present study. These two large pots, known as dolia, have very few parallels in the entire Carpathian Basin, especially the decorated specimen. Before analysing these vessels, a brief preliminary description of the site and the feature is given.
\end{abstract}

Keywords: La Tène C, pottery, dolia

\section{Introduction of the site}

Feature No. 7118 of Perkáta-Nyúli-dűlő, and its pottery assemblage were the main subject of my unpublished BA thesis, on which the present study is based. ${ }^{1}$

Perkáta is located in the eastern part of Fejér county, close to the Danube, in the northern part of the the Mezőföld plain. ${ }^{2}$ The Nyúli-dúlő site lies northwest of the village of Perkáta. This double plateau rises between the Pistola and Genát streams, which flow into each other in its south-eastern corner. ${ }^{3}$ The site was excavated between 2009 and 2011 by the Hungarian National Museum's National Heritage Centre, as the route of the construction of the main road No. 62 crossed the site. In the excavated surface of six hectares (Fig. 1) in addition to the Celtic settlement, a Late Bronze Age settlement and cemetery were identified, as well as a village with several cemeteries used throughout the Middle Ages. ${ }^{4}$

The Late Iron Age settlement, the entirety of which the excavation certainly did not reveal, was located on the western slope of the Nyúli-dúlö, facing the Pistola stream. Based on the reports of similar single-layer flat settlements excavated so far, it can be concluded that the Celts preferred to settle on hillsides and along the banks of watercourses. ${ }^{5}$ The strong erosion of the hillside covering the layer is the reason why the settlement features have survived in relatively good condition, moreover in one case, even the contemporary walkway level can be identified. ${ }^{6} \mathrm{~A}$ total of ten sunken buildings have been excavated, which were associated with the Celtic rural settlement. All the

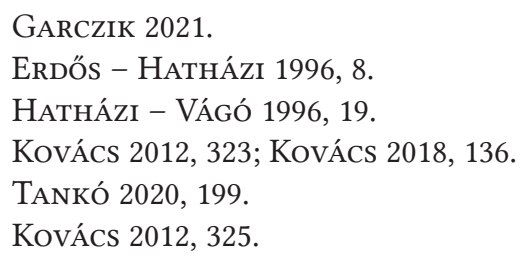


constructions had been burnt down, which caused the end of their use, but no human bodies were recovered from any of them. ${ }^{7}$

Feature No. 7118 (Fig. 2) was located in the western extension of the excavation, on the edge of a forest. It was located very close to the bank of the Pistola stream, with its shorter side facing the watercourse, like the other buildings of the late Iron Age settlement. ${ }^{8}$ The building is rectangular $(425 \times 390 \mathrm{~cm})$, semi-underground $(80 \mathrm{~cm}$ relative depth), with an undivided floor plan. Its relative depth is fairly high among the excavated sunken features of a similar date, although erosion is probably responsible for the shallower ones in other excavations. ${ }^{9}$ Unfortunately, its south-west corner was positioned outside the excavation area, and therefore has not been excavated. Nevertheless, this omission does not make its reconstruction difficult. On its southern side, a projection in the form of a bench was observed; there were three postholes dug into its central longitudinal axis, the posts of which may have supported the roof. In its section, neatly curving bands of burnt rubble could be observed in a concave pattern, which clearly indicates that they stopped using it because of the fire that had destroyed it. Although

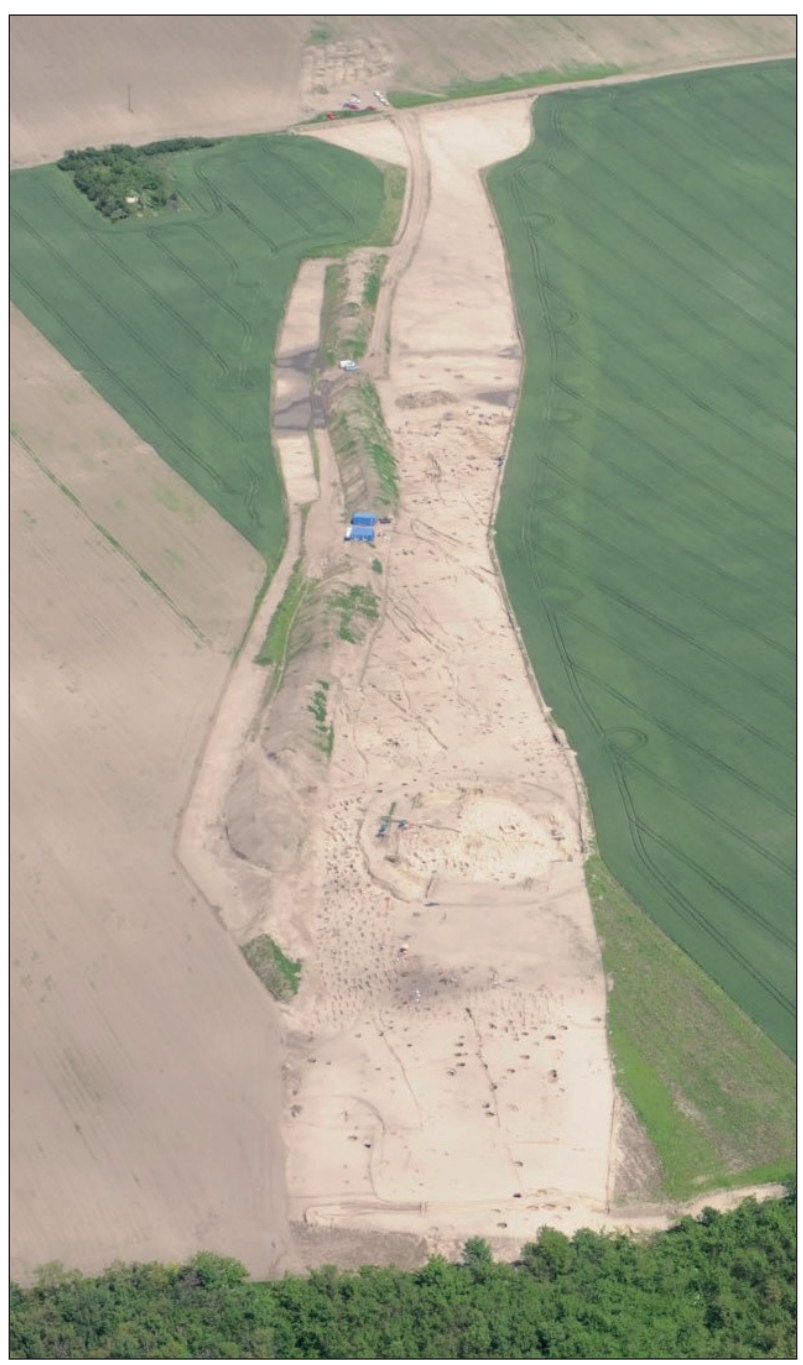

Fig. 1. Aerial photograph of the site Perkáta-Nyúli-dűlő during its excavation (Photo: Z. Czajlik, 28. 05. 2010). it has not been completely excavated, it still provides the largest amount of finds of all the houses in the La Tène (LT) settlement, a phenomenon that perhaps indicates the building's prominent role. In addition to the large number of ceramic fragments, a cattle skeleton in anatomical order, a fragment of a spindle whorl, and a clay disc polished from a ceramic fragment were also found.

As no structures related to the Late Iron Age on the surface of the land are identifiable,${ }^{10}$ it is reasonable to assume that the sunken featured buildings might have served residential functions. This was probably the case for feature No. 7118 as well, as its floor area (approx. $16.6 \mathrm{~m}^{2}$ ) would have accommodated a nuclear family and their furnishings. ${ }^{11}$ If the projection on the south side is taken into account, feature No. 7118 could be associated with the "workshop" house type identified by Lörinc Timár. The main feature of this group of building typology is the bench construction on the longer southern side

$7 \quad$ KovÁcs 2018, 137.

8 Kovács 2012, 325.

9 CZAJLIK et al. 2015, 87.

10 This phenomenon is not unique in the La Tène period of the Carpathian Basin: Timár 2011, 291.

11 This conclusion is drawn because the floor area of the house under study is almost identical to that of the Celtic house in Ráckeresztúr $(4.16 \times 3.9 \mathrm{~m})$, which met the requirements for a dwelling house for a nuclear family (Timár 2010, 270-271). 
of the houses, which probably functioned as an internal staircase or seating area. This may have been the location of the building's relatively wide doorway, which was presumably covered by a canopy. ${ }^{12}$ However, apart from the similarity in form, ${ }^{13}$ the few finds related to crafts (a single spindle whorl fragment) suggest that this building is unlikely to have been used as a workshop, although it is not impossible, given that its finds were probably deposited there secondarily.

\section{The pottery finds}

A total of 584 pottery fragments have been recovered from the site, all of which could be related to the La Téne culture. This is a rather high number, considering the other assemblages from feature dating to this period published so far. ${ }^{14}$ The analysis of these finds has been carried out in the so-called 'Sajópetri system' (which is mainly based on the material quality of the ceramics). Although the Sajópetri system was originally designed for examining the pottery of a settlement in Eastern Hungary with a strong Vekerzug culture tradition, ${ }^{15}$ its introduction in other are-

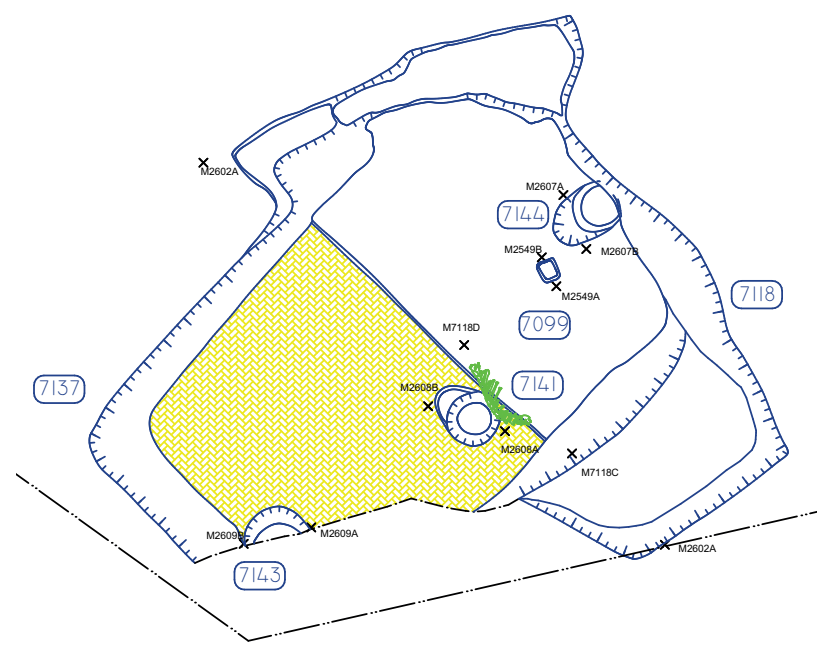

Fig. 2. Floor plan of feature No. 7118. as, in our case in Transdanubia, may be reasonable. ${ }^{16}$ Despite the fact that the cultural influences on Celtic pottery are quite different here, there is a relative basic uniformity throughout the Carpathian Basin, naturally with each region and period having its own specific characteristics: the over- or under-representation of certain types and local variations in form. ${ }^{17}$ By using the system, considerably more statistical data can be extracted from the ceramic material of a Celtic settlement, which not only facilitates the processing of individual examples, but also enables the comparison of several sites, thus contributing to the development of Late Iron Age research in the Carpathian Basin. However, a detailed presentation and analysis of the entire pottery inventory is not the aim of this study.

The ceramic material is rather fragmentary, which is a common phenomenon in La Tène settlements. ${ }^{18}$ Of all the fragments (NR: number of remains / nombres de restes) recovered, relatively few could be restored to form one item, but several unmatched pieces seem to have been part of one vessel. To quantify the ceramic material of an archaeological site or feature, it is essential to calculate the minimum number of individual pieces (MNI / NMI: nombre minimum d'individus), which indicates the minimum number of different vessels that the fragments under study formed part of. ${ }^{19}$

Timár 2011, 298; Timár 2016, 198-200; TANkó 2020, 119.

Though attribution is not perfect: most of the houses classified in this type have only two postholes, while in our case, there are three.

For examples, see: SzABó 2007; TANKó 2020.

For the description of the method, see: SzaBó - TANKó 2007; Szabó 2007.

Szilvia B. Szöllősi has already used the method in this region, see: B. SzöLLŐsI 2014.

SCHWAPPACH 1979; B. SzÖLLősi 2014, 41-42; TANKÓ 2016, 175.

TANKó 2020, 139.

In our case, this was calculated as follows: all the fragments were classified into ten groups according to the Sajópetri system, and within these groups, the edge and base fragments which must have belonged to separate objects were counted; and then those with a higher value were counted further. The values of the groups were finally added together. The method is based on the ceramic statistics system used by Sylvie Barrier and Thierry Luginbühl in Bibracte in 2021 (BARRIER et al. 2021, 232-233). 
In our case, the MNI is 68 , of which about 50 could be identified typologically (TNI: typological number of individual pieces / NTI: nombre typologique d'individus); a similarly high number of identifiable pieces is known from the LT B2-C1 site at Paks-Gyapa. ${ }^{20}$

$67.65 \%$ (46 individual pieces) of the MNI of the ceramic material we have studied were made on a potter's wheel, while $32.35 \%$ (22 individual pieces) were hand-moulded. These proportions are very similar to those of other Celtic settlements in southern and eastern Transdanubia, ${ }^{21}$ while the slightly larger number of handmade wares may reflect eastern influences. Some high-quality handformed pottery was almost indistinguishable from the vessels made on a slow-turning wheel; however, there were also relatively large numbers of fragments of surprisingly poor quality, apparently crude, hand-formed vessels. The latter were presumably made to meet the everyday needs of the household as quickly as possible, ${ }^{22}$ perhaps not by skilled craftsmen, since making such vessels does not require a great deal of skill. In contrast, high-quality ware made on fast-turning wheels shows the advanced craftsmanship of the culture and clearly indicates the hand of specialised potters. It is noteworthy that graphite clay pottery showed a rather high proportion (23.5\% of the MNI); despite the fact that graphite as a raw material was not easily available in the region. ${ }^{23}$

The main characteristic of the Late Iron Age pottery of the Carpathian Basin is the widespread practice of throwing for the first time in the history of the region. Research into the Celtic settlements of Transdanubia has shown that, as the culture spread from the west, it was here that La Tène pottery first appeared, and that in these materials, thrown ware was always predominant. In this region, the new style was mixed with the surviving local traditions of the Hallstatt culture, as well as with southern Illyrian and eastern Scythian influences. ${ }^{24}$ In her 2014 study, Szilvia B. Szöllösi started to outline a regional group in South-Eastern Transdanubia based on the homogeneous pottery material of some LT B2-C1 sites (Paks-Gyapa, Ordacsehi-Csereföld, Harc-Janyapuszta, and Dunaszentgyörgy-Main Road No. 6). ${ }^{25}$ Later, Károly Tankó added the assemblage of the sunken featured building in Ráckeresztúr - near Malontai út to this circle, and pointed out that the settlement of Balatonőszöd-Temetői-dűlő, also in this region, can be dated to a later phase (LT C2-D1). ${ }^{26}$ Since Perkáta is located in this geographical area and its finds show many parallels, it may be stated that this inventory is also related to the group; which the author, in the absence of metal and other small finds, has dated to the La Tène $\mathrm{C} 1-\mathrm{C} 2$ period on the basis of pottery analogies. ${ }^{27}$

B. SzÖLLŐsI 2014, 32. It cannot be excluded that, as in the case of Győr-Ménfőcsanak, the cataloguing of the other Late Iron Age features of the Nyúli-dülő will also reveal pottery fragments that will match potsherds of the structure analysed here, in which case the data given above may change (TANKó 2020, 144).

21 The settlement referred to are: Paks-Gyapa, Ordacsehi-Csereföld, Harc-Janyapuszta, and Dunaszentgyörgy-Main Road No. 6 (B. SzÖLLősı 2014, 31).

22 TANKÓ 2020, 146.

23 This raw material could have come to the Carpathian Basin from present-day Czech Republic, Germany, or Austria. Perkáta was probably connected to these areas by the Danube, although if we accept the intermediary role of Ménfőcsanak in the graphite trade, we can also assume that there were overland routes from there onwards (TANKó 2020, 144-145).

24 TANKó 2016, 167.

25 B. SzÖlıős 2014. For the sites see: VÁczi 2009 (Paks-Gyapa); Gallina et al. 2007 (Ordacsehi-Csereföld); CzAJlik et al. 2010 (Harc-Janyapuszta); SzöLlősı 2009 (Dunaszentgyörgy-Main Road No. 6)

26 TANKó 2016, 170-171.

27 The dating may be greatly influenced by the future processing and interpretation of the finds from other excavated Celtic features. In addition, several scattered metal and glass objects of the Late Iron Age have been recovered from the site, which will also play an important role in clarifying when the site was used, as these groups of objects are more sensitive to cultural changes than ceramics, and thus have a better dating value (B. SzÖLLősi 2014, 28). 


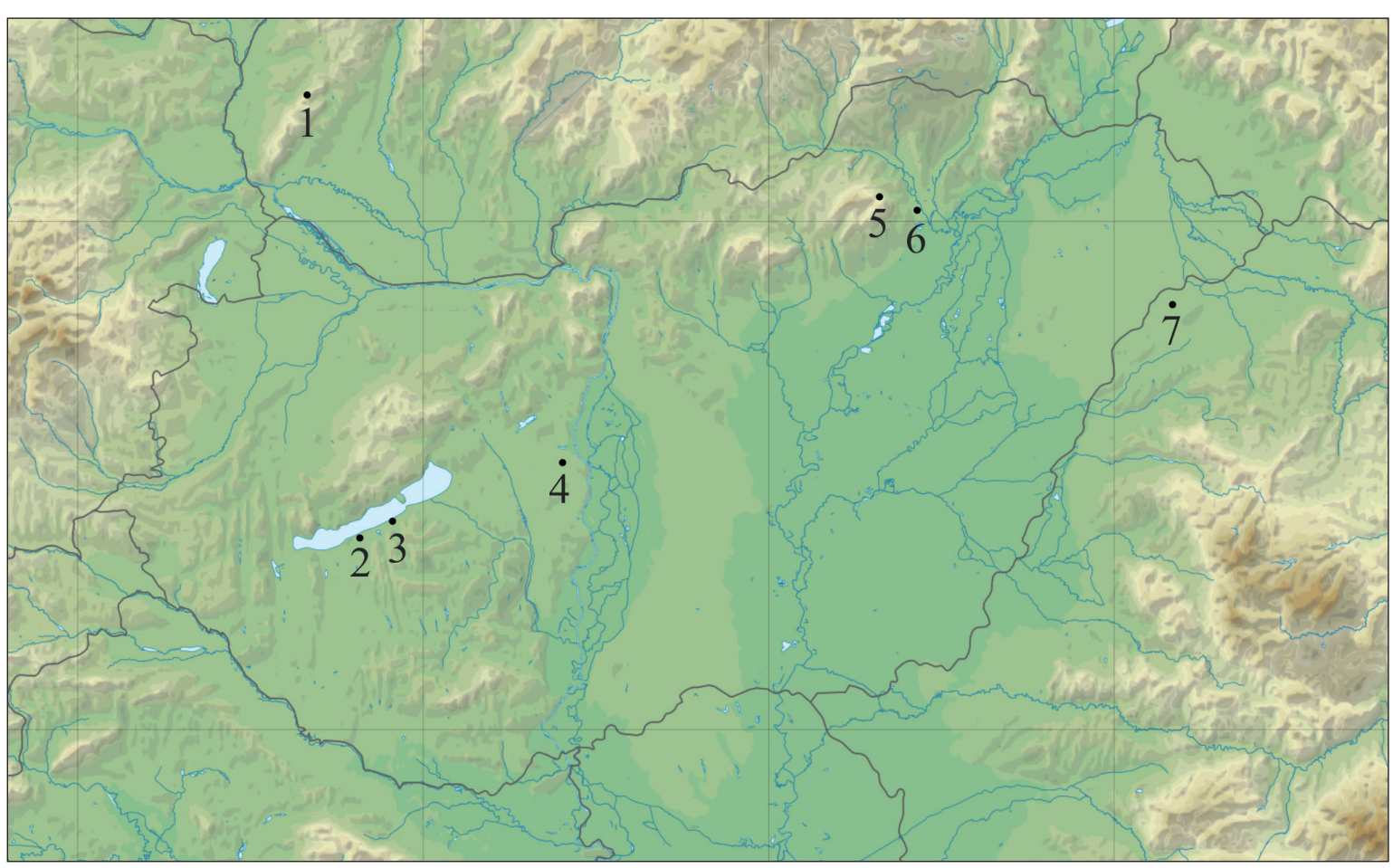

Fig. 3. The earliest known appearences of the dolium type vessels in the Carpathian Basin. 1 - Plavecké Podhradie-Pohanská, 2 - Ordacsehi-Csereföld, 3 - Balatonőszöd-Temetői-dűlő, 4 - Perkáta-Nyúli-dủlő, 5 - Bükkszentlászló-Nagysánc, 6 - Sajópetri-Hosszú-dủlő, 7 - Berea-Nyúlvár.

\section{The dolia}

Two special pieces from the house's ceramic inventory are presented here. The argument for selecting them was their uniqueness and the fact that their formal group is relatively under-researched in Eastern Celtic archaeology.

Large vessels made on potter's wheels are characteristic elements of La Tène ceramics. There is no consensus among researchers concerning the name to denote these objects, as they are known as storage containers (and its synonyms), dolium (pl. dolia) in Latin, and pithos (pl. pithoi) in Greek. ${ }^{28}$ In the Eastern Celtic context, these closed-shaped (biconical or ovoid) vessels have thick walls; they have a wide, flat, convex or ribbed T-shaped rim; they have a rim diameter of at least $26 \mathrm{~cm}$; they are at least $40 \mathrm{~cm} \mathrm{high}^{29}$ and, according to the best-preserved examples, they may be without a handle or provided with two or four knobs, usually at the half of their height. They were probably used for storing liquids or grain ${ }^{30}$ and were covered with some organic material. There are examples of rim fragments that show residues of tar or pine resin for fixing their coverings; traces of these materials have been observed on a piece from Balatonőszöd ${ }^{31}$ and on the mouths of several vessels from the Late Celtic oppidum of Budapest-Gellérthegy-Tabán..$^{32}$ The context of specimens recovered from the Western Celtic areas suggests that they were also used in forges and for salt the Roman vessels of similar shape and function (REPKA 2020, 60).

29 REPKA 2020, 59; SzABó 2007, 242.

30 B. Bónis 1969, 192-193.

31 TANKó 2016, 171. Pl. 4,13.

32 The covering was probably necessary against pests. B. BónIs 1969, 193; Abb. 52,9, Abb. 19,23, Abb. 38,26, Abb. 42,17. 
distillation. ${ }^{33}$ The wide rims of the vessels may have served to prevent spillage and to hold their lids, and their handles may have facilitated their transport because, when full, larger dolia could weigh up to 250 kilos. $^{34}$ There is also evidence of their placement in buildings, since, in addition to Roman analogues, ${ }^{35}$ there are in situ evidences of their sinking in the ground in the Carpathian Basin, in the Late La Tène oppida of Gellérthegy-Tabán ${ }^{36}$ and Bratislava-Devín. ${ }^{37}$ This placement prevented the vessels from being crushed by their weight. ${ }^{38}$ The preparation and firing of dolia must have required a great deal of skill from the potter and a kiln of appropriate size, especially because of their enormous dimensions. ${ }^{39}$

The dolia are characteristic finds of the LT D period in the Carpathian Basin: they are found in the assemblages of almost all villages and fortified settlements of this period, usually in large quantities; but are not yet known from burials. According to Éva B. Bónis, this type of vessel first appeared in the western areas of the La Tène culture, under Greco-Roman influence, and subsequently spread from there to the Carpathian Basin..$^{40}$ In contrast, more dolia are now known from the eastern Celtic areas than from the west, and only in the east are they known from Middle La Tène assemblages. ${ }^{41}$ Therefore, the western origin-theory may not be correct. The Celtic dolia are of much higher quality than the storage containers of the Early Iron Age peoples of the Carpathian Basin, ${ }^{42}$ but they are very similar to the "chiup" type vessels of their eastern neighbours, the Dacians and the Getae, who either adopted the form from the Celts or directly from the Greeks on the Black Sea coast. According to János Németi, the form could have originated directly in the Hellenistic-Greek environment and may have reached the Carpathian Basin via the Celts returning after the Balkan campaigns. ${ }^{43}$ Whether the reason for the spread of the dolia was the practicality of their shape or the transport of the specific materials they contained (e.g., wine), as in the case of the amphorae of the Western Celtic complex ${ }^{44}$ is not yet clear.

In the Carpathian Basin, dolia first appeared in the Middle La Tène period, probably in the LT C1 phase, and their earliest representatives are known from Ordacsehi-Csereföld ${ }^{45}$ and Sajópetri-Hoszszú-dűlon. ${ }^{46}$ Although these sites start already in the LT B2 period, it is likely that these type of vessels appear in their inventory only in their later stages. In addition to these two sites, finds from settlements straddling the LT C2-D1 boundary, such as the two fragments from the Balatonőszöd-Temetői-dűlő ${ }^{47}$ and the Berea-Nyúlvár vessel (end of LT C) ${ }_{9}^{48}$ may also be included here;

B. BónIS 1969, 192.

The latter data is from the late Celtic oppidum of Manching, Germany (REPKA 2020, 153).

REPKA 2020, 153.

B. BóNIS 1969, 192.

In Bratislava-Devín, entire vessels have been excavated from several constructions, buried in the ground up to their shoulders (PIETA 2010, 184).

NÉMETI 1995, 38.

Pieta 2010, 180-184; B. Bónis 1969, 193.

B. BóNIS 1969, 191-192.

REPKA 2020, 144.

PieTA 2010, 184.

The chiup (pl. chiupuri) type refers to large, high quality storage containers from Dacian and Getic sites, which were made on a potter's wheel and have wide, flat rims (NÉmETI 1995, 35-38).

For this, see for example: ThiERrin-Michael et al. 2018.

TANKó 2016, 170; Pl.3/1.II.4.

Szabó 2007, 242; Pl. 11,16, Pl. 19,13, Pl. 24,18, Pl. 33,18, Pl. 36,10, Pl. 75,8, Pl. 98,4, Pl. 101,8, Pl. 118,15, Pl. 119,7, Pl. 127,9, Pl. 133,12.

TANKó 2016, 171, Pl. 4,13,14.

NÉMETI 1995, 35. 
and also dolium finds from the earliest horizon of the oppida: Plavecké Podhradie-Pohanskáa ${ }^{49}$ and Bükkszentlászló-Nagysánc (the dating of the latter is problematic, but it certainly had an early horizon)..$^{50}$ Overall, therefore, we currently know only a few sporadic examples from the entire LT C period (Fig. 3), exclusively from settlements; to which we now add the two vessels from the sunken-featured house of Perkáta-Nyúli-dủlő.

1.29289.7118.216: 12 rim and side fragments of a CCTS dolium. The rim has a rectangular profile and a diameter of $45 \mathrm{~cm}$. The body of the vessel was shaped by hand, and the rim was formed by throwing. One of the fragments is provided with a square knob-handle in a horizontal position, but it is very fragmentary. Its clay is tempered with sand and crushed pottery, and some fragments have a surface smoothed with graphite powder. There are several repair holes, in which, and on the surface of the vessel, there are several traces of corroded iron. A further 19 fragments of the vessel have been deposited under other inventory numbers (Fig. 8,1-7).

1.29289.7118.314: 35 rim and side fragments of a CCTC dolium. The rim has a flat, upward widening profile and a diameter of $36 \mathrm{~cm}$. The body of the vessel was shaped by hand, and the rim was formed by throwing. Two of the fragments have horizontal, ovoid, downward-curving knob-handles. It is not uniform in colour due to its uneven firing. The clay was tempered with sand, and its surface was smoothed after firing. The body of the dolium is decorated with additional smoothed lines, bands, line stacks, and wavy lines. There are several repair holes, in which, and on the surface of the vessel, there are several traces of corroded iron. Sixteen further fragments of the vessel have been deposited under other inventory numbers (Fig. 8,8-9; Fig. 9,1-27; Fig. 4).

The most interesting pottery finds from feature No. 7118 are these two vessels, many sherds of which have been recovered but, unfortunately, only partial restoration has been possible. The traces on the fragments show that, very similarly to the Berea-Nyúlvár dolium, ${ }^{51}$ the bodies of the vessels were built up by hand and the half-finished dolia were then placed on the potter's wheel and their thick rims were reshaped. These are the only two items in the building's inventory made using this technique. The reason for this phenomenon may have been their large size, or the fact that the potter did not have the necessary skills to throw them entirely on the potter's wheel. This method is more frequent in the pottery from other Middle La Tène sites, which proves that this was a common practice. ${ }^{52}$ The CCTS dolium had an angular rim design (Fig. 8,1), similar to the ones known from Sajópetri; ${ }^{53}$ and also had angular-shaped knob-handles (Fig. 8,2). Many of the fragments have a graphite dust smoothed coating, which presumably covered the upper half of the vessel, and the knobs may have been positioned along the vessel's widest diameter.

The CCTC dolium had a flat rim widening upwards (Fig. 8,8-9) and at least two rounded knob-handles (Fig. 8,9,14), probably extending downwards. But what makes this vessel special is its decoration; it is the only decorated dolium from the LT C period that we know of today. Its entire surface was decorated with smoothed ornamentation consisting of simple vertical lines, line stacks, thick bands and wavy lines (Fig. 4). A similar application of smoothing is known from large pots from Ráckeresztúr ${ }^{54}$ and Balatonőszöd. ${ }^{55}$ Apart from the CCTC dolium, the use of a smoothed line

PAulík 1976, 158-159, Tab. 13,5, Tab. 17,1, Tab. 21,1, Tab. 24,4,11, Tab. 25,7, Tab. 29,3, Tab. 33,6, Tab. 35,2, Tab. 37,2, Tab. 38,1, Tab. 71. Jozef Paulík dated the oppidum to the LT D1 period, but Karol Pieta put its beginning to LT C2, and concluded that this is where we currently know the earliest dolia from Slovakia (Pieta 2010, 180, 209).

50 Hellebrandt 1992, 48; 10. ábra,1,8,10-11; TANkó 2016, 189.

51 According to János Németi, the rim and the body of the Berea dolium were made separately, using different techniques and only afterwards were they joined together (NÉmETi 1994, 35). However, the author considers it more likely that the whole vessel was made by hand with the rim left rough, and was reshaped after the vessel had been placed on the wheel.

52 See for example: Dunaszentgyörgy (KREITER et al. 2009, 264-267).

53 Szabó 2007. See footnote No. 41 for the references.

54 Czajlik et al. 2015, Fig. 6,9,12,17.

55 TANkó 2016, Pl. 4,17,19,22,23. 


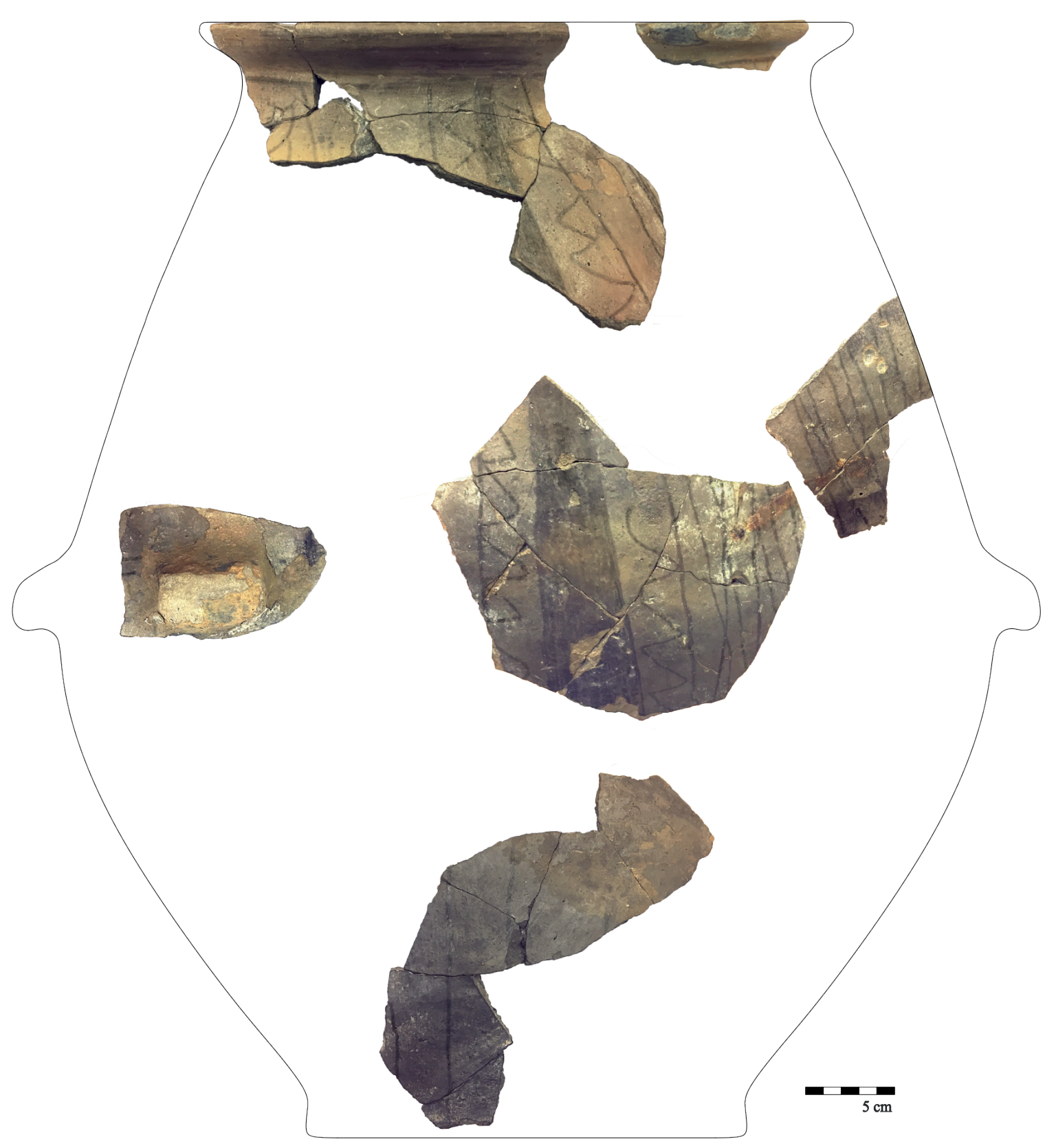

Fig. 4. The hypothetical reconstruction of the CCTC dolium, according to some of its fragments.

decoration could only be identified on one wheel-thrown fragment among the finds of the house (Fig. 5), where the horizontal zigzag line is combined with a horizontal plastic rib. The technique of smoothing appeared in Celtic pottery as early as the LT B2 phase, but only spread widely in the LT C-D period: on the inside of wheel-thrown bowls and on the outside of larger containers in the form of thicker bands, straight and wavy lines, and cross-grid fields. ${ }^{56}$

The main motif of the vessel - an alternation of a vertical wavy line and a thicker band - shows a close relationship with a similar ornamentation on a fragment from Ráckeresztúr, ${ }^{57} \mathrm{a}$ La Tène settlement located just a few kilometres away from Perkáta. These two pots presumably belonged to the same local decorative tradition, the survival of which may be attested by the large painted urns recovered from 
the early imperial eraviscus cemeteries of Nagyvenyim and Lovasberény, also very close to Perkáta. Although figural motifs dominate these centuries younger objects, they also bear wavy lines and line strokes like the ones discussed here, and the shape of the vessels is probably fairly similar too..$^{58}$ This assumption is also based on the fact that very few specimens of Celtic pottery are known from the Carpathian Basin with such complex decorations as the aforementioned examples (especially outside Late La Tène oppida), and that these sites happen to be located in the exact same region. Thus, despite the chronological gap and the functional difference, we might suggest that there is a connection between them.

The importance of both pots from feature No. 7118 is clearly indicated by the fact that many holes indicative of repair can be identified on them (Fig. 8,3-6,9; Fig. 9,1), in which, and in several cases on the surface of the vessels (Fig. 8,3; Fig. 9,1-2), corroded iron was still visible. These traces may suggest that once the vessels were broken, they were not discarded but were held
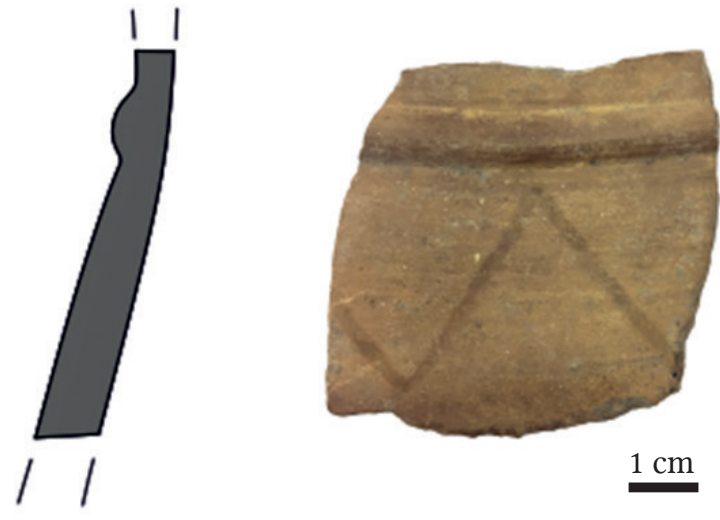

Fig. 5. Fragment No. 1.29289.7118.80 with smoothed decoration.

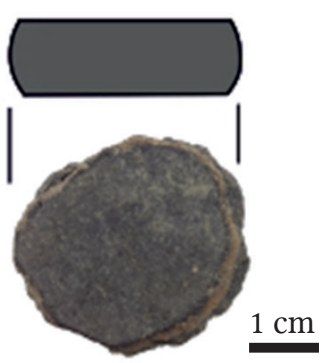

Fig. 6. The clay disc (No. 1.29289.7118.200) made from a sherd of the CCTS dolium. together with iron straps: perhaps because it was difficult to make them, they were hard to replace. In the ceramic material of the sunken featured building, holes made for repairing the vessels were observed in several cases, 17 fragments in all, and metal corrosion was also present on the surface of many sherds, although the latter may not always be due to the iron straps that held the fragments together. Overall, it appears that pottery played an important role in the lives of the people living here, to the extent that they were not immediately thrown away when broken, but the people of the settlement tried to 'restore' them using their own methods. On the one hand, this may indicate that iron was not of such high value in the community that it could not be used for this kind of repair work; on the other hand, it may also reflect that the production of pottery was limited. After all, if new pots were easily available, why would one put so much effort into putting broken ones back together? It may therefore be concluded that pottery, unlike in other places and periods, was relatively valuable here..$^{59}$ This phenomenon most probably continued in the life of the local Celtic communities as late as the beginning of the Common Era, as the excavation of the Perkáta-Sport utca dwelling house, dated to the period after the Roman conquest, has also yielded a number of fragments of repaired pottery. ${ }^{60}$

Based on the material quality and colour of a circular fragment (Fig. 6), which can be identified as a clay disc, it may have belonged to the CCTS dolium. From its shape and the clear grinding marks on its sides, we can assume that it was formed out of a piece of the vessel, once it was irreparable. According to Éva B. Bónis, the pot fragments thus modified can be interpreted also as semi-finished spindle rings

58 For the urns see: B. VÁGó 1960.

59 A similar conclusion was reached by Gertrúda Březinová on the basis of the many repaired fragments recovered from the LT C1-C2/D1 settlement of Hajná Nová Ves (BřEZINová 2013, 120).

60 PONGRÁCZ 1996, 54, 57 
or slingshot balls. ${ }^{61}$ Such objects are relatively popular throughout the La Tène period; similar discs are known, for example, from the Ménfőcsanak, ${ }^{62}$ Gellérthegy-Tabán ${ }^{63}$ and Sajópetri sites. ${ }^{64}$ The long lifespan of this fragment (Fig. 7) is an excellent testimony to the ingenuity of the people living here, and to the importance of ceramics as a raw material in their daily lives.

\section{Conclusion}

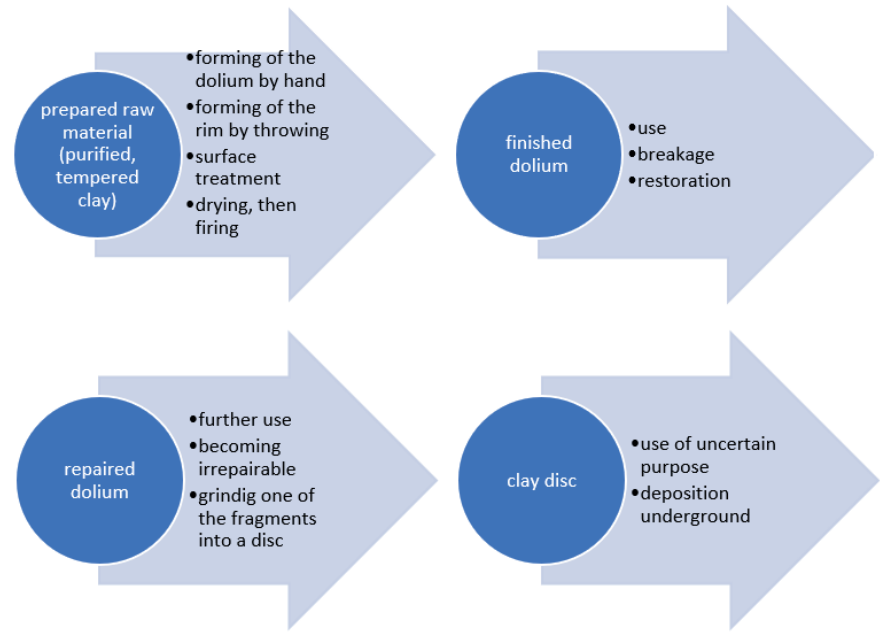

Feature No. 7118 can be identified as a pithouse of the La Tène culture settle-

Fig. 7. The long lifespan of the clay disc.

ment, similar in structure to the 'workshop type'. The end of its use was caused by a fire, which can be inferred from the layers of burnt rubble observed during its excavation. The vast majority of its rich artefactual material consists of fragments of ceramic vessels, which were probably deposited in the rubble of the house secondarily, as it has been impossible to restore any complete vessels. The fragments allow us to draw conclusions about the habits of the users of the house and they also play a major role in dating it.

The pottery material, which dates to the LT C1-C2 period, can be linked to the South-Eastern Transdanubian typological group. The two dolia in the material have rather few parallels from the Middle La Tène period, and no perfect analogy is known for the one with smoothed decoration. The two vessels from Perkáta and the other dolia from this period may be the precursors of the high-quality storage vessels found in large numbers in settlements of the Late La Tène period.

\section{Acknowledgements}

I would like to thank my supervisor, Dániel Szabó for entrusting me with this assemblage and for his help in the process of writing the paper, and Károly Tankó for checking the paper and offering valuable advice. I am grateful to Olivér Loránd Kovács for providing ELTE with the artefacts, without which writing this paper would not have been possible. I am also grateful to Lőrinc Timár for sharing the excavation documentation. I would also like to thank Zoltán Czajlik, Kata Dévai and Eszter Fejér for providing the space necessary for processing the finds even under the current difficult circumstances; and special thanks to Zoltán Czajlik for the aerial photographs and for launching me into writing this study. Finally, I am grateful to Zsuzsanna Siklósi and Márton Szilágyi, as without their course creating plates would not have been possible. 

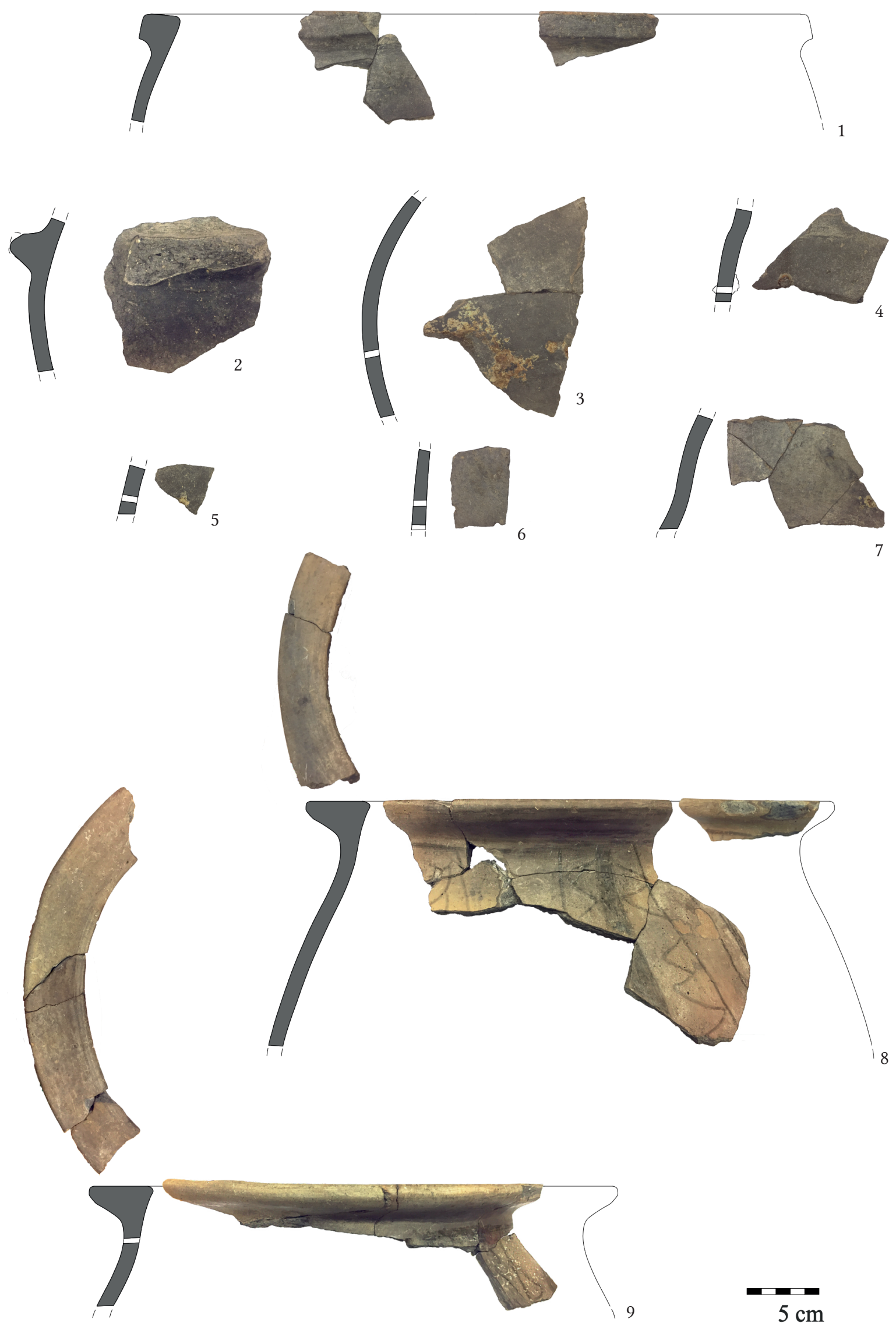

Fig. 8. Fragments of the CCTS dolium (1-7) and the CCTC dolium (8-9). 

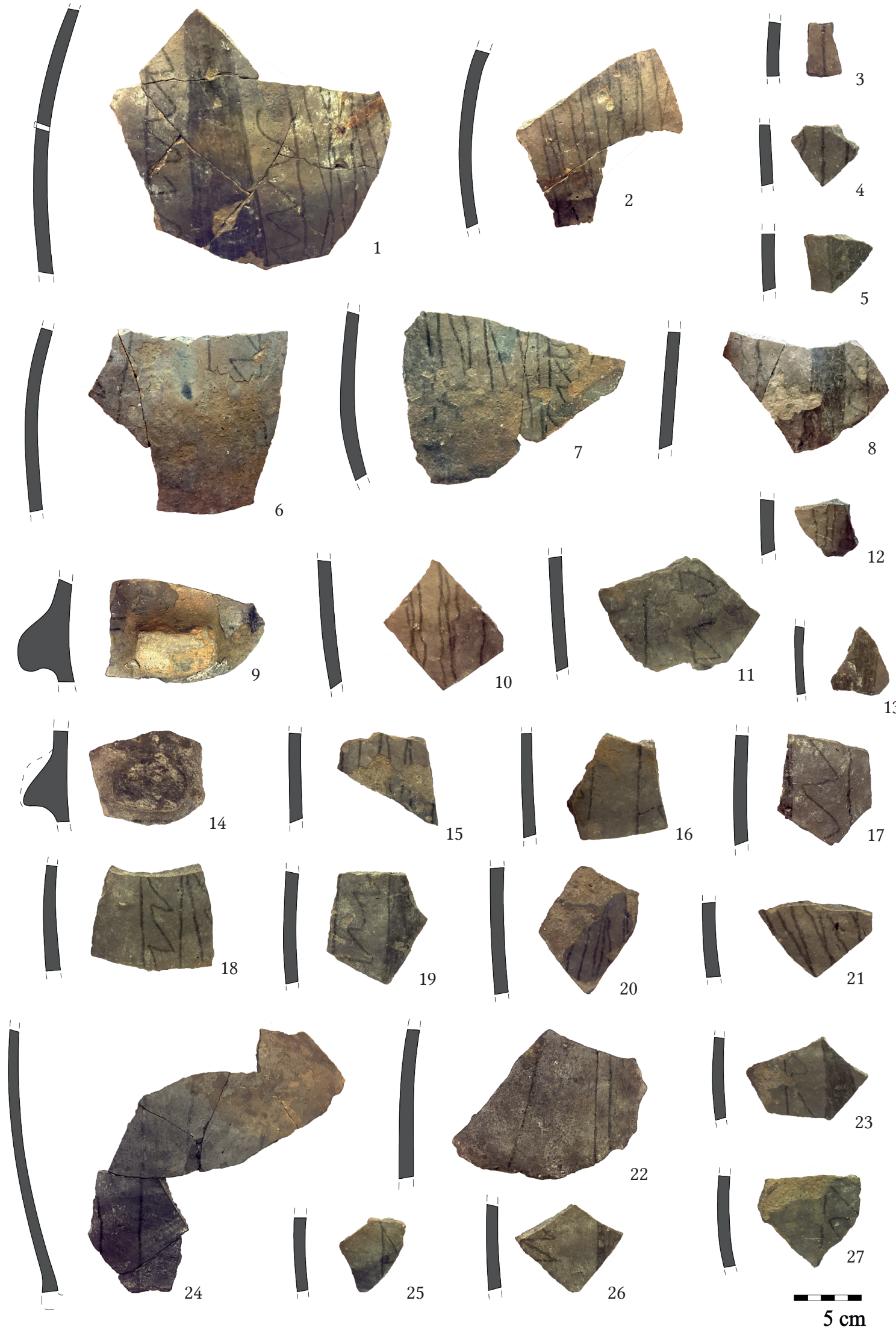

Fig. 9. Fragments of the CCTC dolium. 


\section{References}

B. SzöLlősI, Sz. 2014: La Tène kerámiaművesség a Dél-Dunántúlon. A LT B2-C1 időszakok jellemző kerámiaegyüttesei település-leletanyagok alapján (La Tène Keramikkunst in Südtransdanubien. Typische Keramikgruppen der Perioden LT B2-C1 aufgrund von Siedlungsfundstoffen). Communicationes Archaeologicae Hungariae, 27-48.

B. VÁGÓ, E. 1960: Kelten- und Eraviskengräber von Nagyvenyim und Sárkeszi. Alba Regia 1, 43-62.

BArrier, S. - LuginbüHL, T. - BArral, Ph. 2021: La vaisselle céramique de Bibracte. De l'identification à l'analyse. Collection Bibracte 31. Bibracte.

B. BóNIs, É. 1969: Die Spätkeltische Siedlung Gellérthegy-Tabán in Budapest. Budapest.

BŘEzInovÁ, G. 2013: The Celtic Settlement and its Hinterland. In: Wiedermann, E. (ed.): The Prehistoric Multicultural Settlement of Hajná Nová Ves (Slovakia). Cultural-historical, settlement-archaeological and archaeo-environmental contexts in Western Carpathia at the end of the early prehistoric and in the late prehistoric periods. British Archaeological Reports - International Series 2482. Oxford, 111-134.

Czajlik, Z. - Czövek, A. - Csippán, B. - Holl, B. - Magyari, E. - Szöllősi, Sz. - Rupnik, L. 2010: Archaeological and Paleoenvironmental Data on Late Iron Age Settlements in South-East Transdanubia (Tolna County). In: Berecki, S. (ed.): Iron Age Communities in the Carpathian Basin. Proceedings of the International Colloquium from Târgu Mureş 9-11 October 2009. Biliotheca Mvsei Marisiensis 2. Cluj-Napoca, $149-170$.

CzAjlik, Z. - TANKó, K. - TimáR, L. - Hold, B. 2015: Remains of a Celtic Settlement at Ráckeresztúr. In: Borhy, L. Tankó, K. - Dévai, K. (dir.): Studia archaeologica Nicolae Szabó LXXV annos nato dedicate. Budapest, 77-94.

ERdős, F. - Hatházi, G. 1996: Perkáta története. Dunaújváros.

Gallina, Zs. - Molnár, I. - Somogyi, K. 2007: Ordacsehi-Csereföld. In: Belényesy, K. - Honti, Sz. - Kiss, V. (szerk.): Gördülő idő. Régészeti feltárások az M7-es autópálya Somogy megyei szakaszán Zamárdi és Ordacsehi között. Budapest-Kaposvár, 197-206.

GARCZIK, Á. 2021: Egy késő vaskori gödörház régészeti leletanyagának elemzése Perkáta-Nyúli-dülőről. Unpublished BA Thesis. Eötvös Loránd University, Budapest.

Hatházi, G. - VÁgó, Cs. 1996: Perkáta régészeti lelőhelyei. In: Erdős, F. - Hatházi, G. (szerk.): Perkáta története. Dunaújváros, 14-25.

Hellebrandt, M. 1992: Miskolc kelta kora (Das keltische Zeitalter von Miskolc). In: Rémiás, T. (szerk.): Régészeti tanulmányok Miskolc korai történetéből. Miskolc, 33-74.

KovÁcs, L. O. 2012: 390. Perkáta, Nyúli-dűlő. In: Kisfaludi, J. (szerk.): Régészeti kutatások Magyarországon 2010 - Archaeological Investigations in Hungary 2010. Budapest, 323-326.

KovÁcs, L. O. 2018: 274. Perkáta, Nyúli-dűlő. In: Kisfaludi, J. - Kvassay, J. - Kreiter, A. (szerk.): Régészeti kutatások Magyarországon 2011 - Archaeological Investigations in Hungary 2011. Budapest, 136-139.

Kreiter, A. - Bajnóczi, B. - Havancsák, I. - Tóth, M. - Szakmány Gy. 2009: Kelta kerámiák makroszkópos és archaeometriai vizsgálata. In: Kvassay, J. (szerk.): Település- és temetőfeltárás Dunaszentgyörgy határában. VIA - Kulturális Örökségvédelmi Kismonográfiák / VIA - Monographia Minor in Cultural Heritage 1. Budapest, 157-199.

NÉmeti, J. 1995: Vas-Chiup Descoperit la Berea (Com. Sanislau) Jud. Satu Mare (A Large Vessel [Dolia] from Berea, Sanislău Village, Satu Mare County). Satu Mare 11-12, 33-39.

PAulík, J. 1976: Keltské hradisko Pohanská v Plaveckom Podhradí (Der keltische Burgwall Pohanská in Plavecké Podhradie). Bratislava.

PIEtA, K. 2010: Die Keltische Besiedlung der Slowakei. Füngere Latènezeit. Archaeologica Slovaca Monographiae. Nitra. 
Pongrácz, Zs. 1996: Rómaikor. In: Erdős, F. - Hatházi, G. (szerk.): Perkáta története. Dunaújváros, 53-61.

RePKA, D. 2020: Laténska Keramika Ako Predmet Štúdia. Nitra.

SchwAPpACH, F. 1979: Zur Chronologie der östlichen Frühlatène-Keramik. Bad Bramstedt.

Szabó, D. - Tankó, K. 2007: Présentation du systeme de gestion de céramique de Sajópetri (Hongrie). Ösrégészeti levelek / Prehistoric Newsletters 8-9, 168-177.

Szabó, M. 2007 (dir.): L’habitat de l'époque de La Tène á Sajópetri-Hosszú-düló. Budapest.

SzöLlősI, Sz. 2009: Kelta település részlete a Kr.e. 3. századból. In: Kvassay, J. (szerk.): Település- és temetőfeltárás Dunaszentgyörgy határában. VIA - Kulturális Örökségvédelmi Kismonográfiák / VIA Monographia Minor in Cultural Heritage 1. Budapest, 123-156.

TANKó, K. 2016: Chronological Aspects of Ceramic Types from Recently Investigated La Tène Settlements in Hungary. In: Berecki, S. (ed.): Iron Age Chronology in the Carpathian Basin. Proceedings of the International Colloquium from Târgu Mureş, 8-10 October 2015. Cluj-Napoca, 165-189.

TANKó, K. 2020: Egy kelta falu Győr határában. A ménföcsanaki késó vaskori település. Studien zur Eisenzeit im Ostalpenraum 2. Budapest.

Thierrin-Michael, G. - Tretola Martinez, D. C. - Serneels, V. 2018: Assessment of the amphora spectrum in a rural Late La Tène settlement at Reinach-Nord, Basel region, Switzerland. Fournal of Archaeological Science: Reports 21, 1055-1063. DOI: 10.1016/j.jasrep.2017.11.039

TIMÁr, L. 2010: Les reconstitutions possibles des constructions de l'Âge du fer, découvertes à Ráckeresztúr. In: Borhy, L. (red.): Studia celtica classica et romana Nicolae Szabó septuagesimo dedicata. Budapest, 261-272.

TimÁr, L. 2011: Késő vaskori veremházak maradványainak értelmezése. Ősrégészeti levelek - Prehistoric Newsletters 13, 290-303.

TimÁR, L. 2016: The Sunken-Featured Buildings of the Middle La Tène Period: Problems and Reconstructions. In: Karwowski, M. - Ramsl, P. C. (eds): Boii - Taurisci: Proceedings of the International Seminar, OberleisKlement, June $14^{\text {th }}-15$ th, 2012. Vienna, 191-206.

VÁczi, G. 2009: Paks-Gyapa, M6 TO-15. lelőhely. In: Kisfaludy, J. (szerk.): Régészeti Kutatások Magyarországon 2008 - Archaeological Investigations in Hungary 2008. Budapest, 253-255.

(c) 2022 The Author(s).

cc) (i) (5) This is an open-access article distributed under the terms of the Creative Commons Attribution-Non Commercial 4.0 International Licence (CC BY-NC 4.0). 